\title{
THE ORCHARD ARCHITECTURE DEDICATED FOR MECHANICAL HARVESTING OF DESSERT PLUMS AND PRUNES
}

\author{
Augustyn MIKA, Zbigniew BULER*, Jacek RABCEWICZ, Paweł BIAŁKOWSKI, \\ Dorota KONOPACKA \\ Research Institute of Horticulture \\ Konstytucji 3 Maja 1/3, 96-100, Skierniewice, Poland
}

Received: August 2018; Accepted: June 2019

\begin{abstract}
Two plum cultivars 'Record' and 'Empress' and one prune cultivar 'Common Prune' were planted in spring 2014, spaced at $4.5 \times 1.5 \times 2.0 \mathrm{~m}$, to be trained to the "Y"- and "V"-trellising systems for mechanical harvesting of dessert fruits with a canopy-contact harvester. The applied trellising systems were compared with the standard central leader system at the same spacing. Trellised trees showed a tendency to grow less well than leader-trained trees, but during the four years of training, they created a higher canopy volume than the control trees because of their spreading form. Trellised trees were able to give yields comparable to those of standard trees. Light distribution within the tree canopy was acceptable in all the training systems. After 4 years of training, the trees were suitable for mechanical harvesting. The effectiveness of mechanical harvesting varied from $85 \%$ to $90 \%$. The quality of the fruits harvested with a canopy-contact harvester was comparable to that of manually picked fruits. The consumption of quality of fruits after mechanical harvesting rated on a 5-grade scale was 0.5 grade lower than that of manually harvested fruits. These fruits were acceptable in the local fruit market. Mechanical harvesting was 10-30 times faster compared to manual picking. The cost of the trellising system calculated per 1 ha was 2.0 times higher than that of the standard system.
\end{abstract}

Keywords: fruit harvesting, stone fruits, trellising systems, illumination

\section{INTRODUCTION}

During the recent years, some positive results have been obtained in mechanical harvesting of soft fruits produced for industrial processing. Several fruit tree species such as cherries, olives, plums, and fruit bushes are mechanically harvested (Jiménez et al. 2011; Ferguson et al. 2012; Mika et al. 2012; Rabcewicz et al. 2017). Experimental work is still being conducted to improve the harvesting technology (Amphatzidis et al. 2012; Larbi \& Karkee 2014; He et al. 2015). Mechanical fruit harvesting by means of trunk shakers is mostly performed, but it has several disadvantages, particularly fruit bruising and low effectiveness of fruit collection (CastroGarcia et al. 2012). Mechanical harvesting of dessert soft fruits has not yet been solved satisfactorily.
Semi-dwarf trees planted at high density are suitable to be harvested with a canopy-contact harvester (Mika et al. 2012). Small trees planted at high density may produce as much large yield as that of tall trees planted at low density (Mika \& Buler 2011; Botu et al. 2013; Day et al. 2013). Trials with mechanical harvesting of stone fruits designed for the fresh market have revealed that tree architecture is very important. Trees should have only one layer of branches, similar to the letter "Y" or "V". Day et al. (2013) compared these forms with standard leader trees and found that tall trees were only slightly more productive than low spread trees. Several trials with high-density planting of semi-dwarf plum trees have confirmed the opinion on their high productivity (Mika et al. 2012, 2015; Botu et al. 2013; Day et al. 2013; Murri et al. 2013). 
Mechanical harvesting of plums designed for processing has already been solved. Mika et al. (2012) demonstrated mechanical harvesting of densely planted plum trees trained to the central leader, and pruned by the renewal method, by a selfpropelled straddle canopy-contact harvester. Harvesting rate was $2-3 t \cdot h^{-1}$ an the effectiveness was 90-95\%. The harvester was designed for industrial processed plums, but the quality of small-sized plums and prunes was so good that, after sorting, $80 \%$ were suitable for the fresh market. In another trial, an effort was made to mechanically harvest dessert quality plums from trees planted at high density and trellised as horizontal canopy (such as the letter "T") (Mika et al. 2016). The trees were suitable for harvesting with a small tractor-driven canopy-contact harvester, but the growth of the trees was not satisfactory.

In a trials by Amphatzidis et al. (2012), Larbi and Karkee (2014), and He et al. (2015), sweet cherry trees were trained with a limited number of branches. There were only 3 or 4 main limbs on the side to act on, so as to limit fruit damage when falling down. A catching conveyer was designed to intercept falling fruit without damage. Mechanically harvested cherries had only $5-10 \%$ more damage than hand-harvested cherries. The experimental harvester demonstrated potential for harvesting stalkless sweet cherries with $82-95 \%$ fresh market quality and only $5-10 \%$ more damage compared to commercial hand harvesting.
Recent trials on harvesting plums and sour cherries for industrial processing with a straddle, canopycontact harvester, constructed at the Research Institute of Horticulture in Skierniewice, have revealed that the harvester is able to collect fruit with $85-90 \%$ efficiency at a rate of 3-4 $\mathrm{t} \cdot \mathrm{h}^{-1}$ (Mika et al. 2015).

The aim of this work was to proof that the form "horizontal canopy" may facilitate mechanical harvesting plums and prunes designed for dessert purposes.

\section{MATERIALS AND METHODS}

The main target of the trial was to create new orchard architecture suitable for harvesting dessert fruit of plum and prune for the fresh market and to evaluate the "Y"- and "V"-trellised systems in comparison with the standard central leader system.

In the trial presented here, new canopy architecture was created. Trees were trellised on a metal structure to form a flat continuous fruiting wall in the row at three alternative angles to the horizontal: $20^{\circ}, 30^{\circ}$, and $45^{\circ}$ (Figs. $1 \& 2$ ). To obtain the wall, trees were spaced $4.5 \mathrm{~m}$ between rows and 1.5 and $2.0 \mathrm{~m}$ in the row, and trellised on wires. In a trellised orchard, a tractor with a harvesting unit might be moving along the inter-rows, with the shaking unit acting in the tree canopy and the grabbing unit collecting fruit under tree canopies. The distance from fruit stem to the grabbing unit would be short, 0.7$1.5 \mathrm{~m}$, creating conditions for gentle collection of the falling fruits during shaking.

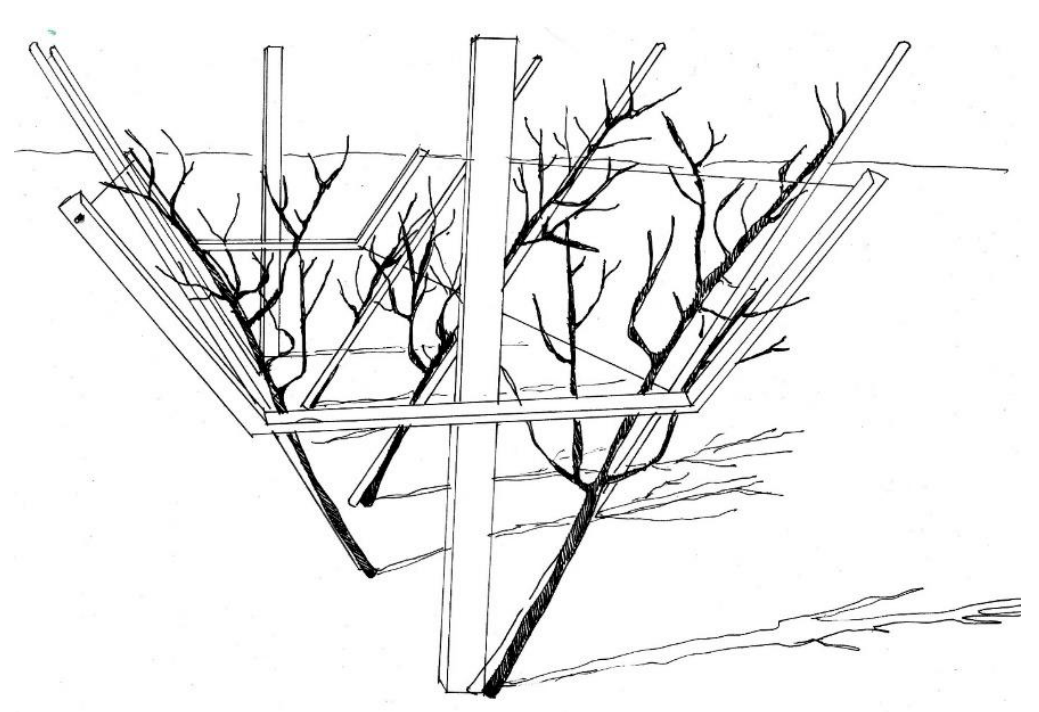

Fig. 1. Tree training systems for plum and prune harvesting - "V" system 


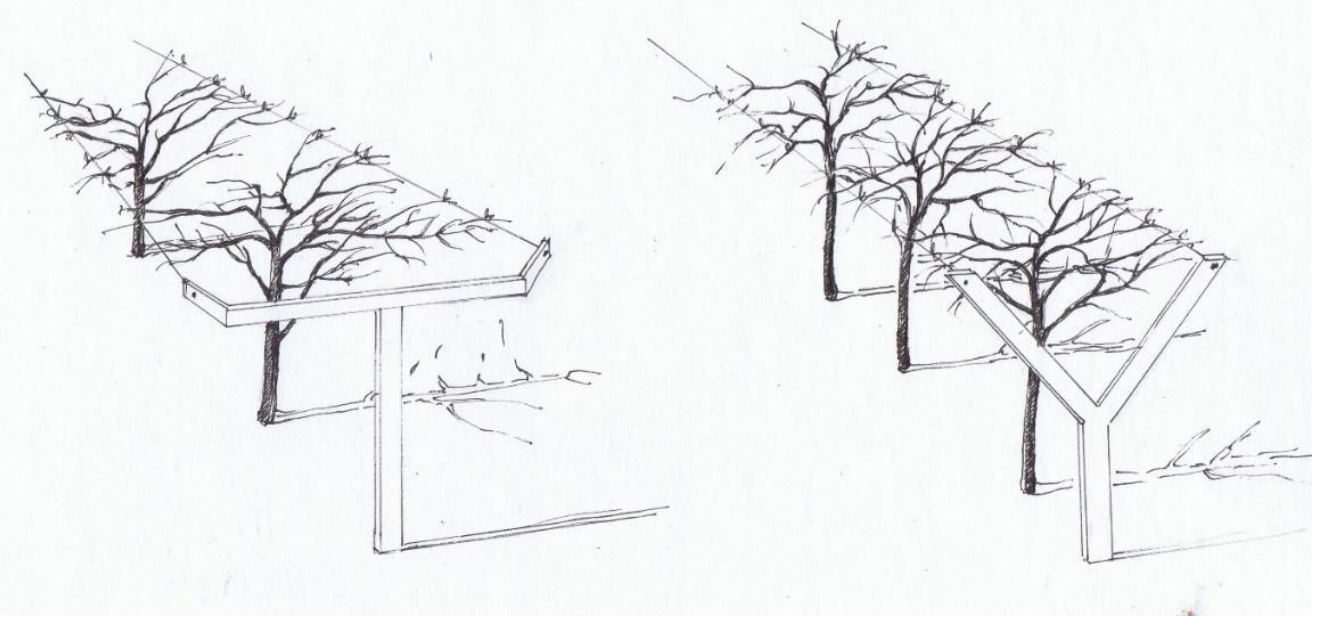

Fig. 2. Tree training systems for plum and prune harvesting - "Y" system with branches trained in horizontal and slant position

In March 2014, an experimental plot was planted at the Research Institute of Horticulture in Skierniewice, Poland, in an area of 0.75 ha. The following trees of plum cultivars were planted: 'Record' and 'Empress' were grafted on semi-dwarf rootstock 'Wangenheim Prune'; also one prune cultivar 'Common Prune' was grafted on Prunus cerasifera.

There were four methods of tree training: (1) tree training to "Y" canopy with branches at $20^{\circ}$ up to horizontal, (2) tree training to "Y" canopy with branches at $30^{\circ}$ up to horizontal, (3) tree training to "V" canopy with branches at $45^{\circ}$ up to horizontal, and (4) control: tree training to central leader canopy with the leader tied to a pole.

To mount the trellising support, galvanized metal profiles (c-beam) with a dimension of $60 \times 60$ $\times 4 \mathrm{~mm}$ were mounted in the ground at a distance of $10 \mathrm{~m}$ apart, to a depth of $0.8 \mathrm{~m}$. The first support in the row was reinforced in the ground with concrete. On the vertical support, at a height of $0.8 \mathrm{~m}$, metal arms were mounted aslant at $20^{\circ}$ and $30^{\circ}$. On these arms, 4 wires were stretched along the row at a distance of 0.5 and $1.0 \mathrm{~m}$ from the row center on both sides. The trellising enabled the creation of a continuous 2-m wide and 50-m long canopy. To obtain the "V" system, metal poles were driven into the ground, $10 \mathrm{~m}$ apart, aslant at $45^{\circ}$, and two wires were stretched in each row. Stakes were mounted at each tree, directed at $45^{\circ}$. The control trees, trained to the central leader, were tied to metal poles driven $0.8 \mathrm{~m}$ into the ground at each tree to a height of $2.5 \mathrm{~m}$. The control trees were trained to the standard method. In the first year, shoots were lightly tipped to induce vigorous growth. The leader shoot was tied vertically to the pole and the side shoots were directed to a slant or horizontal position with pins (clips) in May to form wide angles. This treatment was repeated in the second year on trees that required such a correction. Pruning the trees designed to "V"- and "Y"-trellising after planting was nearly the same as for the control trees, but the lowest laterals up to $0.8 \mathrm{~m}$ were removed, because they would interfere with the work of the harvester. In the first year, it was necessary to bend 4-10 summer shoots to the wires and, in the second year, twice as many. In the third year, some supplementary bending was indispensable.

To create conditions for the continuous moving of the harvester, each cultivar was planted in a separate $160-\mathrm{m}$ long row. The rows were divided across into three blocks with a length of $50 \mathrm{~m}$ each. Each block consisted of four replications treated as a repetition. In each replication, there were six or seven uniformly treated trees. On these plots, for a period of 3 years, tree growth vigor was assessed by taking annual measurements of the trunk's diameter, converted later into the trunk's cross-sectional area.

When orchard architecture is altered from the standard to a novel training system, the light microclimate is also varied. To evaluate light relation within the trees, solar irradiation was measured in the fourth year of the trial, in August 2017, with a portable solarimeter Sun Scan Probe type SS1 (Delta-T Devices Ltd., England). The measurements were performed only on sunny days around midday. The irradiation 
results expressed in $\mathrm{W} \cdot \mathrm{m}^{-2}$ were converted to the percentage of light within the tree canopy in relation to the irradiation above the canopy. These results were treated as illumination levels within the tree canopy. Light interception by the trees was calculated as the difference between total light irradiation minus irradiation at the bottom levels of the canopy.

The time of harvest was estimated based on the force fruit retention measured before harvesting with electronic dynamometer. Large-sized plum 'Record' were harvested at a force of $9.4 \mathrm{~N}$, 'Empress' at 7.2 N, and small-sized 'Common Prune' at 5.5 N.

Manual harvesting and mechanical harvesting were performed on the same day. To compare the quality of fruit harvested from the investigated tree canopies, on the day of the harvest, samples of fruit without visible signs of damage were first checked for mean weight, soluble solids, acidity, and firmness, as well as anthocyanin content and antioxidant activity. On the day of the harvest, the quality of plum and prune fruit was characterized. For each cultivar, 4 samples of 25 fruits with stems each were cut off the trees. First, the force $(\mathrm{N})$ needed to detach fruit from stem was measured with a digital dynamometer. Then, the mean weight of a single fruit was recorded $( \pm 0.01 \mathrm{~g})$. Fruit firmness $(\mathrm{N})$ was measured with an Instron 4303 machine and expressed as the force needed to puncture the fruit with a $3.5-\mathrm{mm}$ diameter probe moving at a speed of $50 \mathrm{~mm} \cdot \mathrm{min}^{-1}$. Also, the soluble solids, titratable acidity, and total anthocyanin content were determined for each combination.

Moreover, the fruit was stored at 0 and $8{ }^{\circ} \mathrm{C}$ and was checked after 5 and then 10 days, to ascertain its storability and ability to maintain quality in the market place. Along with the determination of fruit quality on the day of the harvest, the suitability of mechanically harvested yield for storage was also compared with the quality of handpicked fruits. For the storability test, only wholesome fruits without any visible defects were taken. Both kinds of samples consisted of 20 fruits, which were stored for 5 days at a temperature of $18^{\circ} \mathrm{C}$, and for 10 days in a cold store $\left(0^{\circ} \mathrm{C}\right)$. The quality of the fruit was checked twice, first, after 1 day of storage and then after the end of the storage test. The sensory quality was evaluated by using a consensus method carried out by a three-person team. Sensory assessment included traits describing the appearance of the fruit and the taste and texture, with consumption quality determined by the results of the aforementioned characteristics. For each quality attribute, a fivepoint scale was established with certain end point definitions.

The direct cost of establishing a trellised orchard compared to a standard orchard was calculated by adding the cost of soil cultivation, fertilization, cost of trees, supporting system, and trellised wires. The cost of the experimental plots was calculated per 1 ha.

The results were evaluated statistically and presented in tables and graphs. The results were statistically analysed using one-way analysis of variance (ANOVA) separately for each cultivar, followed by means separation with Duncan's multiplerange t-test at $\mathrm{P}<0.05$. In the case of overall consumption quality, two-way ANOVA has been used with additional factor - storage duration.

\section{RESULTS AND DISCUSSION}

Tree vigor expressed by the trunk cross-sectional area (TCSA) revealed a weaker growth of the trellised trees in comparison with the control trees, but the differences were mostly insignificant. The weakest growth was proved only for the trees trained to the "V" system. Trees of "Common Prune' were the most vigorous in all the training systems (Table 1). Trees trained to horizontal canopy with branches positioned at $30^{\circ}$ showed the most uniform growth of shoots and were the most suitable for mechanical harvesting.

It had been expected that the trellised trees would produce less annual growth and form a more compact canopy than the control trees because of shoot bending that might retard shoot growth. It can be demonstrated that shoot bending might cause some mechanical deterioration of shoot tissues, which would retard the transport of minerals and photosynthetic products. Robinson (2017) demonstrated that "V"-shaped canopies form thin fruiting wall have very good distribution and interception. The trees trained to the "Y" system produced a significantly higher canopy volume than the control 
and "V" system trees because of their more spreading habit (Table 2).

Trees in all the training systems came into bearing in the third year from planting. A commercial yield was obtained in the fourth year (2017). The yield was mainly affected by the cultivar and less by the training system (Tables $3 \& 4$ ).
The trial showed that the trellised trees were able to come into bearing at the same time as the leadertrained trees and produce comparable or even higher yields. Fruit load as the ratio of the yield to the canopy volume $\left(\mathrm{kg} \cdot \mathrm{m}^{-3}\right)$ was not affected much by the training system except for the "V" system, in which the smallest canopy produced the highest fruit load (Table 5).

Table 1. Trunk cross-sectional area $\left(\mathrm{cm}^{2}\right)$ in the fourth year from planting (2017)

\begin{tabular}{lcccc}
\hline \multirow{2}{*}{ Cultivar } & \multicolumn{4}{c}{ Tree training system } \\
\cline { 2 - 5 } & \multirow{2}{*}{ control - hand harvesting } & \multicolumn{3}{c}{ trellised trees - mechanical harvesting } \\
\cline { 2 - 5 } & $38.9 \mathrm{a} \pm 2.04 *$ & "Y" at $20^{\circ}$ & "Y" at $30^{\circ}$ & "V" at $45^{\circ}$ \\
\hline 'Record' & $25.8 \mathrm{a} \pm 3.07$ & - & - & $30.2 \mathrm{~b} \pm 2.63$ \\
'Empress' & $48.4 \mathrm{a} \pm 4.95$ & $41.9 \mathrm{~b} \pm 1.42$ & $23.0 \mathrm{ab} \pm 1.72$ & $19.2 \mathrm{~b} \pm 1.85$ \\
'Common Prune' & & & $45.8 \mathrm{ab} \pm 2.50$ & - \\
\hline
\end{tabular}

*means in each line followed by the same letter do not differ significantly according to Duncan's test at $\mathrm{p}=0.05 ;$ means $\pm \mathrm{SD}$

Table 2. Canopy volume $\left(\mathrm{m}^{3}\right)$ in the fourth year from planting (2017)

\begin{tabular}{lcccc}
\hline \multirow{2}{*}{ Cultivar } & \multicolumn{4}{c}{ Tree training system } \\
\cline { 2 - 5 } & \multirow{2}{*}{ control - hand harvesting } & \multicolumn{3}{c}{ trellised trees - mechanical harvesting } \\
\cline { 3 - 5 } & $4.6 \mathrm{~b} \pm 0.12^{*}$ & $7.6 \mathrm{a} \pm 0.12$ & - & $3.4 \mathrm{c} \pm 0.12$ \\
\hline 'Record' & $2.7 \mathrm{~b} \pm 0.12$ & - & $4.7 \mathrm{a} \pm 0.12$ & $3.0 \mathrm{~b} \pm 0.12$ \\
'Empress' & $9.9 \mathrm{c} \pm 0.12$ & $10.9 \mathrm{~b} \pm 0.12$ & $12.9 \mathrm{a} \pm 0.12$ & - \\
\hline
\end{tabular}

*Note: see Table 1

Table 3. Fruit yield (kg per tree) in the fourth year from planting (2017)

\begin{tabular}{lcccc}
\hline \multirow{2}{*}{ Cultivar } & \multicolumn{4}{c}{ Tree training system } \\
\cline { 2 - 5 } & \multirow{2}{*}{ control - hand harvesting } & \multicolumn{3}{c}{ trellised trees - mechanical harvesting } \\
\cline { 2 - 5 } & $15.1 \mathrm{~b} \pm 1.87^{*}$ & $18.7 \mathrm{ab} \pm 0.41$ & - & "V" at $45^{\circ}$ \\
\hline 'Record' & $7.3 \mathrm{a} \pm 2.24$ & - & $8.3 \mathrm{a} \pm 0.20$ & $9.3 \mathrm{a} \pm 1.32$ \\
'Empress' & $4.5 \mathrm{a} \pm 1.16$ & $4.5 \mathrm{a} \pm 0.20$ & $6.5 \mathrm{a} \pm 0.20$ & - \\
\hline
\end{tabular}

*Note: see Table 1

Table 4. Total yield (kg per tree; 2015-2017)

\begin{tabular}{lcccc}
\hline \multirow{2}{*}{ Cultivar } & \multicolumn{4}{c}{ Tree training system } \\
\cline { 2 - 5 } & \multirow{2}{*}{ control - hand harvesting } & \multicolumn{3}{c}{ trellised trees - mechanical harvesting } \\
\cline { 2 - 5 } & $18.7 \mathrm{~b} \pm 1.81^{*}$ & $27.3 \mathrm{a} \pm 0.41$ & - & "V" at $45^{\circ}$ \\
\hline 'Record' & $13.0 \mathrm{a} \pm 2.21$ & - & $15.1 \mathrm{a} \pm 0.25$ & $16.3 \mathrm{a} \pm 0.40$ \\
'Empress' & $9.1 \mathrm{a} \pm 1.20$ & $7.8 \mathrm{a} \pm 0.22$ & $9.7 \mathrm{a} \pm 0.22$ & - \\
\hline
\end{tabular}

*Note: see Table 1 
Table 5. Fruit load (expressed in $\mathrm{kg}$ of fruit per $\mathrm{m}^{3}$ canopy volume; 2017)

\begin{tabular}{|c|c|c|c|c|}
\hline \multirow{3}{*}{ Cultivar } & \multicolumn{4}{|c|}{ Tree training system } \\
\hline & \multirow{2}{*}{ control - hand harvesting } & \multicolumn{3}{|c|}{ trellised trees - mechanical harvesting } \\
\hline & & "Y" at $20^{\circ}$ & "Y" at $30^{\circ}$ & "V" at $45^{\circ}$ \\
\hline 'Record' & $3.3 \mathrm{~b} \pm 0.12^{*}$ & $2.5 \mathrm{c} \pm 0.12$ & - & $5.9 \mathrm{a} \pm 0.12$ \\
\hline 'Empress' & $2.7 \mathrm{a} \pm 0.12$ & - & $1.8 \mathrm{~b} \pm 0.12$ & $3.1 \mathrm{a} \pm 0.12$ \\
\hline 'Common Prune' & $0.5 \mathrm{a} \pm 0.06$ & $0.4 \mathrm{a} \pm 0.06$ & $0.5 \mathrm{a} \pm 0.06$ & - \\
\hline
\end{tabular}

*Note: see Table 1

Table 6. Percentage of light distributed to the inner parts of tree canopy on two levels (2017)

\begin{tabular}{|c|c|c|c|c|}
\hline \multirow{3}{*}{$\begin{array}{l}\text { Measuring levels } \\
\text { (m) }\end{array}$} & \multicolumn{4}{|c|}{ Tree training system } \\
\hline & \multirow{2}{*}{$\begin{array}{c}\text { control - hand } \\
\text { harvesting }\end{array}$} & \multicolumn{3}{|c|}{ trellised trees - mechanical harvesting } \\
\hline & & "Y" at $20^{\circ}$ & "Y" at $30^{\circ}$ & "V" at $45^{\circ}$ \\
\hline \multicolumn{5}{|c|}{ 'Record' } \\
\hline 1.5 & $35.7 \mathrm{a} \pm 18.99^{*}$ & $41.8 \mathrm{a} \pm 44.20$ & - & $39.9 \mathrm{a} \pm 46.57$ \\
\hline 0.7 & $17.0 \mathrm{a} \pm 29.46$ & $5.6 \mathrm{~b} \pm 5.25$ & - & $15.9 \mathrm{a} \pm 10.61$ \\
\hline \multicolumn{5}{|c|}{ 'Empress' } \\
\hline 1.5 & $52.8 \mathrm{~b} \pm 20.69$ & - & $61.6 \mathrm{a} \pm 36.73$ & $60.9 \mathrm{a} \pm 32.49$ \\
\hline 0.7 & $25.1 \mathrm{~b} \pm 24.13$ & - & $19.5 \mathrm{~b} \pm 13.13$ & $30.9 \mathrm{a} \pm 16.96$ \\
\hline \multicolumn{5}{|c|}{ 'Common Prune' } \\
\hline 1.5 & $17.8 \mathrm{~b} \pm 5.55$ & - & $45.6 \mathrm{a} \pm 17.10$ & - \\
\hline 0.7 & $6.2 \mathrm{~b} \pm 2.86$ & - & $9.4 \mathrm{a} \pm 3.92$ & - \\
\hline
\end{tabular}

*Note: see Table 1

Table 7. Percentage of light intercepted by the tree canopy (summer 2017)

\begin{tabular}{lcccc}
\hline \multirow{2}{*}{ Cultivar } & \multicolumn{4}{c}{ Tree training system } \\
\cline { 2 - 4 } & \multirow{2}{*}{ control - hand harvesting } & \multicolumn{2}{c}{ trellised trees - mechanical harvesting } \\
\cline { 3 - 5 } & & "Y" at 20 & "Y" at 30 & "V" at 45 \\
\hline 'Record' & 83.0 & 94.4 & - & 84.1 \\
'Empress' & 74.9 & - & 80.5 & 69.1 \\
'Common Prune' & 93.8 & - & 90.6 & - \\
\hline
\end{tabular}

Light levels (Table 6) measured in the fourth year (2017) at the upper part of tree canopy (1.5 m above the ground) revealed that trees in all the training systems were sufficiently illuminated when compared to the recommended minimum value of $30 \%$. Irradiation varied between $35 \%$ and $61 \%$ of the light level coming from above the orchard. Only strong growing trees of 'Common Prune' trained to the leader form showed illumination ranging from $17 \%$ to $45 \%$. Measurements performed at the lowest part of tree canopies, at their base, revealed very low light intensities, except in the "V" system. These last results indicated that most of the canopies very effectively intercepted solar irradiation. The canopy plane should be rather divided into two planes stretched along the row and inclined at a certain angle to the horizontal, similar to that in the "V" training system (Buler \& Mika 2009; Krueger et al. 2013; Mika \& Buler 2016).

Light interception calculated as the percentage of incoming light to the tree canopies minus the amount of light on the ground level varied depending on the training system (Table 7). Light interception should be at least $30 \%$ of the irradiation incoming to the orchard (He et al. 2008; Corelli-Grappadelli et al. 2017; Robinson 2017).

The results showed (Table 7) that "Y"-trellised trees have higher ability to intercept sunlight than "V"trellised trees. Mechanical harvesting of 'Record' fruit was 20 times faster, 'Empress' was 10 times faster, and 'Common Prune' was 30 times faster compared to manual picking (Table 8). The new method of tree training presented here and mechanical harvesting 
of plum and prune fruits might solve the problem of deficit of hand labor in fruit production.

In the third year after planting (2016), the first yield from the control and trellised trees was harvested manually. In the fourth year (2017), fruits were picked manually from the leader-trained trees and with the harvesting machine from the trellised trees. Basic quality of the fruit harvested manually - mean fruit weight, firmness, TSS (total soluble solids), acidity - showed no significant differences between the training systems (Tables 9-11) except in three cases: mean fruit weight of 'Record' plum and 'Common Prune' in 2016 and 2017 and TSS of 'Empress' plum in 2016.

Table 8. Time consumption of fruit harvested manually by one person compared to mechanical harvesting by two persons, expressed in kg per hour, in the fourth year from planting (2017)

\begin{tabular}{|c|c|c|c|c|c|}
\hline \multirow{3}{*}{ Cultivar } & \multirow{3}{*}{ Mode of harvesting } & \multicolumn{4}{|c|}{ Tree training system } \\
\hline & & \multirow{2}{*}{ control } & \multicolumn{3}{|c|}{ trellised trees } \\
\hline & & & "Y" at $20^{\circ}$ & "Y" at $30^{\circ}$ & "V" at $45^{\circ}$ \\
\hline \multirow{2}{*}{ 'Record' } & manual & 130 & - & - & 94 \\
\hline & mechanical & - & 2615 & - & - \\
\hline \multirow{2}{*}{ ‘Empress’ } & manual & 85 & - & - & 122 \\
\hline & mechanical & - & - & 1160 & - \\
\hline \multirow{2}{*}{ 'Common Prune' } & manual & 20 & - & - & - \\
\hline & mechanical & - & 520 & 750 & - \\
\hline
\end{tabular}

Table 9. Characteristics of 'Record' fruit

\begin{tabular}{|c|c|c|c|c|c|c|}
\hline \multirow{4}{*}{ Fruit quality } & \multicolumn{6}{|c|}{ Tree training system } \\
\hline & \multirow{2}{*}{\multicolumn{2}{|c|}{ control - hand harvesting }} & \multicolumn{4}{|c|}{ trellised trees - mechanical harvesting } \\
\hline & & & \multicolumn{2}{|c|}{ "Y" at $20^{\circ}$} & \multicolumn{2}{|c|}{ "Y" at $30^{\circ}$} \\
\hline & 2016 & 2017 & 2016 & 2017 & 2016 & 2017 \\
\hline Mean fruit weight $(\mathrm{g})$ & $68.5 \mathrm{~b} \pm 1.72 *$ & $78.4 \mathrm{a} \pm 2.21$ & $68.3 \mathrm{~b} \pm 1.85$ & $70.1 \mathrm{~b} \pm 1.59$ & - & - \\
\hline Firmness (N) & $8.67 \mathrm{a} \pm 2.32$ & $4.96 \mathrm{~b} \pm 1.05$ & $8.16 \mathrm{a} \pm 1.84$ & $5.56 \mathrm{~b} \pm 1.00$ & - & - \\
\hline TSS (\%) & $17.9 \mathrm{a} \pm 0.46$ & $15.5 \mathrm{~b} \pm 0.69$ & $17.1 \mathrm{a} \pm 0.68$ & $14.4 \mathrm{~b} \pm 0.75$ & - & - \\
\hline Acidity (\%) & $0.941 \mathrm{a} \pm 0.05$ & $0.807 \mathrm{~b} \pm 0.03$ & $0.971 \mathrm{a} \pm 0.03$ & $0.878 \mathrm{~b} \pm 0.04$ & - & - \\
\hline $\begin{array}{l}\text { Anthocyanin content } \\
\left(\mathrm{mg} \cdot 100 \mathrm{~g}^{-1}\right)\end{array}$ & $12.9 \mathrm{a} \pm 3.28$ & $11.5 \mathrm{ab} \pm 2.11$ & $10.5 \mathrm{~b} \pm 2.18$ & $8.78 \mathrm{~b} \pm 1.89$ & - & - \\
\hline $\begin{array}{l}\text { Antioxidant value - Trolox } \\
\left(\mathrm{mg} \cdot 100 \mathrm{~g}^{-1}\right)\end{array}$ & $1.93 \mathrm{a} \pm 0.18$ & $2.18 \mathrm{a} \pm 0.21$ & $2.17 \mathrm{a} \pm 0.53$ & $1.88 \mathrm{a} \pm 0.14$ & - & - \\
\hline
\end{tabular}

*Note: see Table 1

Table 10. Characteristics of 'Empress' fruit

\begin{tabular}{|c|c|c|c|c|c|c|}
\hline \multirow{4}{*}{ Fruit quality } & \multicolumn{6}{|c|}{ Tree training system } \\
\hline & \multirow{2}{*}{\multicolumn{2}{|c|}{ control - hand harvesting }} & \multicolumn{4}{|c|}{ trellised trees - mechanical harvesting } \\
\hline & & & \multicolumn{2}{|c|}{ "Y" at $20^{\circ}$} & \multicolumn{2}{|c|}{ "Y" at $30^{\circ}$} \\
\hline & 2016 & 2017 & 2016 & 2017 & 2016 & 2017 \\
\hline Mean fruit weight $(\mathrm{g})$ & $58.4 \mathrm{~b} \pm 1.77 *$ & $70.4 \mathrm{a} \pm 2.04$ & - & - & $60.4 b \pm 1.33$ & $70.4 \mathrm{a} \pm 2.23$ \\
\hline Firmness (N) & $12.0 \mathrm{a} \pm 3.49$ & $5.87 \mathrm{~b} \pm 2.19$ & - & - & $11.9 \mathrm{a} \pm 3.48$ & $5.97 \mathrm{~b} \pm 2.70$ \\
\hline TSS (\%) & $18.1 \mathrm{~b} \pm 0.54$ & $18.2 \mathrm{~b} \pm 0.35$ & - & - & $19.2 \mathrm{a} \pm 0.75$ & $18.3 b \pm 0.69$ \\
\hline Acidity $(\%)$ & $1.423 \mathrm{~b} \pm 0.09$ & $1.510 \mathrm{a} \pm 0.07$ & - & - & $1.470 \mathrm{ab} \pm 0.02$ & $1.481 \mathrm{ab} \pm 0.04$ \\
\hline $\begin{array}{l}\text { Anthocyanin content } \\
\left(\mathrm{mg} \cdot 100 \mathrm{~g}^{-1}\right)\end{array}$ & $15.3 \mathrm{~b} \pm 3.11$ & $25.8 \mathrm{a} \pm 4.10$ & - & - & $18.9 \mathrm{ab} \pm 2.90$ & $22.9 \mathrm{a} \pm 3.45$ \\
\hline $\begin{array}{l}\text { Antioxidant value - } \\
\text { Trolox }\left(\mathrm{mg} \cdot 100 \mathrm{~g}^{-1}\right)\end{array}$ & $1.25 \mathrm{~b} \pm 0.21$ & $2.37 \mathrm{a} \pm 0.15$ & - & - & $1.23 \mathrm{~b} \pm 0.12$ & $2.36 \mathrm{a} \pm 0.25$ \\
\hline
\end{tabular}

*Note: see Table 1 
Table 11. Characteristics of 'Common Prune' fruit

\begin{tabular}{|c|c|c|c|c|c|c|}
\hline \multirow{4}{*}{ Fruit quality } & \multicolumn{6}{|c|}{ Tree training system } \\
\hline & \multicolumn{2}{|c|}{ control - hand harvesting } & \multicolumn{4}{|c|}{ trellised trees - mechanical harvesting } \\
\hline & & & \multicolumn{2}{|c|}{ "Y" at $20^{\circ}$} & \multicolumn{2}{|c|}{ "Y" at $30^{\circ}$} \\
\hline & 2016 & 2017 & 2016 & 2017 & 2016 & 2017 \\
\hline Mean fruit weight $(\mathrm{g})$ & $20.5 \mathrm{c} \pm 0.39 *$ & $22.9 \mathrm{~b} \pm 0.59$ & $22.8 \mathrm{~b} \pm 0.24$ & $23.3 \mathrm{~b} \pm 0.53$ & $22.7 \mathrm{~b} \pm 0.34$ & $24.1 \mathrm{a} \pm 0.68$ \\
\hline Firmness (N) & $9.66 \mathrm{a} \pm 3.48$ & $6.05 \mathrm{~b} \pm 1.45$ & $9.79 \mathrm{a} \pm 2.60$ & $5.81 \mathrm{~b} \pm 1.97$ & $9.97 \mathrm{a} \pm 2.53$ & $5.98 \mathrm{~b} \pm 1.90$ \\
\hline TSS (\%) & $22.7 \mathrm{a} \pm 0.72$ & $21.9 \mathrm{~b} \pm 0.67$ & $23.7 \mathrm{a} \pm 0.65$ & $21.8 \mathrm{~b} \pm 0.45$ & $23.5 \mathrm{a} \pm 0.34$ & $21.1 \mathrm{~b} \pm 0.29$ \\
\hline Acidity (\%) & $0.907 \mathrm{a} \pm 0.06$ & $0.690 \mathrm{~b} \pm 0.03$ & $0.900 \mathrm{a} \pm 0.04$ & $0.732 \mathrm{~b} \pm 0.05$ & $0.873 \mathrm{a} \pm 0.04$ & $0.737 b \pm 0.06$ \\
\hline $\begin{array}{l}\text { Anthocyanin content } \\
\left(\mathrm{mg} \cdot 100 \mathrm{~g}^{-1}\right)\end{array}$ & $10.6 \mathrm{~b} \pm 0.92$ & $13.3 \mathrm{a} \pm 1.48$ & $10.8 \mathrm{~b} \pm 1.29$ & $14.4 \mathrm{a} \pm 2.08$ & $11.2 \mathrm{~b} \pm 0.96$ & $12.5 \mathrm{ab} \pm 1.89$ \\
\hline $\begin{array}{l}\text { Antioxidant value - Trolox } \\
\left(\mathrm{mg} \cdot 100 \mathrm{~g}^{-1}\right)\end{array}$ & $0.71 \mathrm{~b} \pm 0.08$ & $2.27 \mathrm{a} \pm 0.21$ & $0.95 \mathrm{~b} \pm 0.16$ & $2.74 \mathrm{a} \pm 0.32$ & $0.73 \mathrm{~b} \pm 0.011$ & $2.15 \mathrm{a} \pm 0.18$ \\
\hline
\end{tabular}

*Note: see Table 1

Table 12. Overall consumption quality of the fruit after short cold storage

\begin{tabular}{|c|c|c|c|c|c|c|}
\hline \multirow{4}{*}{$\begin{array}{l}\text { Storage du- } \\
\text { ration }\end{array}$} & \multicolumn{6}{|c|}{ Tree training system } \\
\hline & \multicolumn{3}{|c|}{ Refrigerator $8^{\circ} \mathrm{C}$} & \multicolumn{3}{|c|}{ Cold storage room $0{ }^{\circ} \mathrm{C}$} \\
\hline & \multirow{2}{*}{$\begin{array}{l}\text { control - hand har- } \\
\text { vesting }\end{array}$} & \multicolumn{2}{|c|}{$\begin{array}{l}\text { trellised trees - mechanical } \\
\text { harvesting }\end{array}$} & \multirow{2}{*}{$\begin{array}{l}\text { control - hand har- } \\
\text { vesting }\end{array}$} & \multicolumn{2}{|c|}{$\begin{array}{c}\text { trellised trees }- \text { mechanical } \\
\text { harvesting }\end{array}$} \\
\hline & & "Y" at $20^{\circ}$ & "Y" at $30^{\circ}$ & & "Y" at $20^{\circ}$ & "Y" at $30^{\circ}$ \\
\hline \multicolumn{7}{|c|}{ 'Record' } \\
\hline 5 days & $4.5 \mathrm{a}^{*}$ & $4.0 \mathrm{a}$ & - & $4.5 \mathrm{a}$ & $4.0 \mathrm{a}$ & - \\
\hline 10 days & $2.5 \mathrm{bc}$ & $2.0 \mathrm{c}$ & - & $4.0 \mathrm{a}$ & $3.0 \mathrm{~b}$ & - \\
\hline \multicolumn{7}{|c|}{ 'Empress' } \\
\hline 5 days & $3.5 \mathrm{ab}$ & - & $3.5 \mathrm{ab}$ & $4.0 \mathrm{a}$ & - & $3.5 \mathrm{ab}$ \\
\hline 10 days & $3.0 \mathrm{~b}$ & - & $2.5 \mathrm{c}$ & $3.5 \mathrm{ab}$ & - & $3.0 \mathrm{~b}$ \\
\hline \multicolumn{7}{|c|}{ 'Common Prune' } \\
\hline 5 days & $3.5 \mathrm{ab}$ & $3.0 \mathrm{~b}$ & $3.0 \mathrm{~b}$ & $4.0 \mathrm{a}$ & $3.5 \mathrm{ab}$ & $3.5 \mathrm{ab}$ \\
\hline 10 days & $3.0 \mathrm{~b}$ & $3.0 \mathrm{~b}$ & $3.5 \mathrm{ab}$ & $3.5 \mathrm{ab}$ & $3.0 \mathrm{~b}$ & $3.0 \mathrm{~b}$ \\
\hline
\end{tabular}

*Rating system: 5 - very good, 4 - good, 3 - medium, 2 - bad, 1 - very bad; means for a particular cultivar followed by the same letter do not differ significantly according to Duncan's test at $p=0.05$

In the fourth year from planting (2017), fruit harvesting from the trellised trees was performed with the harvesting machine working in continuous motion, and the results were compared with manual harvesting. Fruit from the control leader trees were picked manually. The harvester was able to harvest fruits with an efficiency of $85-90 \%$. The remaining $10-15 \%$ of the fruit was left on the trees or fell to the ground. These results proved Peterson (2005) opinion that successful mechanical harvesting of fresh market-quality deciduous tree fruit will only occur when plant characteristics and machine designs are integrated into compatible system. According to Castro-Garcia et al. (2012), the efficiency of canopy contact harvesters is not usually greater than $80-90 \%$. The quality of mechanically harvested fruit was the most important aspect because they were intended for the local market as dessert fruit. The basic quality features of the fruit picked manually from the control and trellised trees did not differ much. As the main goal of the developed technology was to supply the market with dessert fruit for direct consumption, a sensory assessment of fruit subjected to short-term cold storage was carried out. The results of the sensory assessment presented in Table 12 show that the quality of the fruit harvested mechanically was usually perceived about 0.5 grade lower on a 5 -grade of validation in comparison with manual harvesting. However, it was also proved that the mechanically harvested 
fruits could maintain higher than "medium" consumption quality for up to 5 days. The conditions of regular cold storage $\left(0{ }^{\circ} \mathrm{C}\right)$ turned out to be more favorable toward preserving the quality of the investigated plum and prune batches.

The cost of establishing an orchard with the supporting system would be twice as high as that of a standard orchard. The main value in the high cost of the trellised orchard was the supporting system. It was constructed out of high-quality galvanized steel. In practice, it could be constructed at a lower cost, but even so the trellised orchard would be at least $50 \%$ more expensive than a standard orchard. The direct costs of establishing 1 ha of a trellised orchard compared to a standard, intensive orchard (assuming that, in both systems, trees are spaced at $4.5 \times 1.5 \mathrm{~m}$ ) are as follows: costs of trellised orchard of stone fruits (in Euros): soil cultivation, farm manure, mineral fertilizers $=930$, trees 1,480 $\times 3.5=5,180$, irrigation system $=4,651$, supporting system of galvanized steel $=17,104$, galvanized wires $=900$, total $=28,765$; costs of standard orchard (in Euros): soil cultivation, farm manure, mineral fertilizers $=930$, trees $1,480 \times 3.5=5,180$, irrigation system $=4,651$, supporting system (metal galvanized poles and wires $)=3,719$, total $=14,480$.

\section{CONCLUSIONS}

1. Plum and prune trees trellised on a supporting structure to a flat, continuous fruit wall are able to produce a commercial crop in the fourth year from planting.

2. Trellised trees can produce a yield and quality fruit comparable to those of leader-trained trees.

3. The canopy-contact harvester designed at the Research Institute of Horticulture in Skierniewice, Poland, is able to harvest plum and prune fruits with an efficiency of 85-90\%.

4. Mechanically harvested plums and prunes reach a quality level which is almost as good as that of manually picked fruit, although they are yet to be fully accepted in the market.

5. Mechanical harvesting is $10-30$ faster than manual harvesting.
6. The cost of establishing an orchard with a structure for trellising trees is 2.0 times higher than that of a standard orchard.

7. The shortage of hand labor for fruit harvesting might be an obstruction in plum production development and mechanical harvesting would be necessary.

\section{Acknowledgment}

This publication was produced under project No. PBS2/A8/21/2013 "Development of the technology of cultivation and mechanical harvesting of dessert fruit: plums, sour cherries and sweet cherries". The project was cofinanced by the National Centre for Research and Development (NCBR) within the framework of the Applied Research Programme (PBS).

\section{REFERENCES}

Amphatzidis Y.G., Qin Z., Whiting M. 2012. Comparing the efficiency of future harvest technologies for sweet cherry. Acta Horticulturae 965: 195-198. DOI: 10.17660/actahortic.2012.965.26.

Botu M., Mitra Amza M., Botu I., Papachatzis A. 2013. European plum (Prunus domestica L.) cultural systems trial. Acta Horticulturae 985: 169-173. DOI: 10.17660/actahortic.2013.985.20.

Buler Z., Mika A. 2009. The influence of canopy architecture on light interception and distribution in 'Sampion' apple trees. J. of Fruit and Ornam. Plant Res. 17(2): 45-52.

Castro-Garcia S., Blanco Roldan G.L., Jimenez-Jimenez F., Gil-Ribes J.A., Ferguson L., Glozer K., Krueger W.H., Fichtner E.J., Burns J.K., Miles J.A., Rosa U.A. 2012. Preparing Spain and California table olive industries for mechanical harvesting. Acta Horticulturae 965: 29-40. DOI: 10.17660/actahortic.2012.965.1.

Corelli-Grappadelli L., Lopez G., Manfrini L., Zibord M., Morandi B., Bastias R., Losciale P. 2017. Conditioning the orchard light environment for greater efficiency and sustainability. Acta Horticulturae 1177: 73-78. DOI: $10.17660 /$ actahortic.2017.1177.7.

Day K., Johnson R.S., DeJong T.M. 2013. Developing a pedestrian plum orchard: the role of tree form, density and height. Acta Horticulturae 985: 175180. DOI: 10.17660/actahortic.2013.985.21. 
Ferguson L., Glozer K., Crisosto C., Rosa U.A., CastroGarcia S., Fichtner E.J., Guinard J.X., Lee S.M., Krueger W.H., Miles J.A., Burns J.K. 2012. Improving canopy contact olive harvester efficiency with mechanical pruning. Acta Horticulturae 965: 83-87. DOI: 10.17660/actahortic.2012.965.8.

He F., Wang F., Wei Q., Wang X., Zhang Q. 2008. Relationships between the distribution of relative canopy light intensity and the peach yield and quality. Agr. Sci. China 7(3): 297-302. DOI: 10.1016/s1671-2927(08)60069-3.

He L., Zhou J., Zhang Q, Karkee M. 2015. Evaluation of multipass mechanical harvesting on 'Skeena' sweet cherries trained to Y-trellis. HortScience 50(8): 1178-1182. DOI: 10.21273/hortsci.50.8.1178.

Jiménez R., Rallo P., Suárez M.P., Morales-Sillero A.M., Casanova L., Rapoport H.F. 2011. Cultivar susceptibility and anatomical evaluation of table olive fruit bruising. Acta Horticulturae 924: 419-424. DOI: 10.17660/actahortic.2011.924.53.

Krueger W.H., Niederholzer F.J.A., Fichtner E. 2013. Investigation of pruning strategies for dried plums including hand, mechanical and combinations. Acta Horticulturae 985: 201-207. DOI: 10.17660/actahortic.2013.985.25.

Larbi P.A., Karkee M. 2014. Effects of orchard characteristics and operator performance on harvesting rate of a mechanical sweet cherry harvester. GSTF Journal on Agricultural Engineering 1(1): 1-11. DOI: $10.5176 / 2345-7848 \_1.1 .1$.

Mika A., Buler Z. 2011. Intensive plum orchard with summer training and pruning. Advances in Horticultural Science 25(3): 193-198. DOI: 10.13128/ahs-12769.

Mika A., Buler Z. 2016. Light relations in a plum orchard trellised horizontally in comparison with standard, central leader training. Journal of Horticultural Research 24(2): 31-36. DOI: 10.1515/johr-2016-0018.

Mika A., Wawrzyńczak P., Buler Z., Konopacka D., Konopacki P., Krawiec A. et al. 2012. Mechanical harvesting of plums for processing with a continuously moving combine harvester. Journal of Fruit and Ornamental Plant Research 20(1): 29-42. DOI: 10.2478/v10290-012-0003-y.

Mika A., Buler Z., Rabcewicz J., Białkowski P., Konopacka D. 2015. Suitability of plum and prune cultivars, grown in a high density planting system, for mechanical harvesting with a canopy contact, straddle harvester. Journal of Horticultural Research 23(2): 69-81. DOI: 10.2478/johr-2015-0017.

Mika A., Buler Z., Rabcewicz J., Białkowski P., Konopacka D. 2016. Horizontal canopy for plums mechanically harvested in continuous motion. Acta Scientiarum Polonorum, Hortorum Cultus 15(6): 49-59.

Murri G., Massetani F., Neri D. 2013. Crop load and fruit quality of 'Fortune' plum. Acta Horticulturae 985: 213-219. DOI: 10.17660/actahortic.2013.985.27.

Peterson D.L. 2005. Harvest mechanization progress and prospects for fresh market quality deciduous tree fruits. HortTechnology 15(1): 72-75. DOI: 10.21273/horttech.15.1.0072.

Rabcewicz J., Mika A., Buler Z., Białkowski P. 2017. Preliminary valuation of "Y" and "V"-trellised canopies for mechanical harvesting of plums, sweet cherries and sour cherries for the fresh market. Journal of Horticultural Research 25(2): 27-35. DOI: 10.1515/johr-2017-0019.

Robinson T.L. 2017. Can we manage light interception levels above $70 \%$ in apple orchards? Acta Horticulturae 1177: 79-86. DOI: 10.17660/actahortic.2017.1177.8. 